Universidad

:\% de Alcalá

\title{
BIBLIOTECA
}

Document downloaded from the institutional repository of the University of Alcala: https://ebuah.uah.es/dspace/

This is a postprint version of the following published document:

González-Moreiras, M. et al., 2017. Cleavage of Dinitrogen from Forming Gas by a Titanium Molecular System under Ambient Conditions. Chemistry - A European Journal, 23(15), pp.3558-3561.

Available at https://doi.org/10.1002/chem.201700152

(C) 2017 Wiley-VCH.

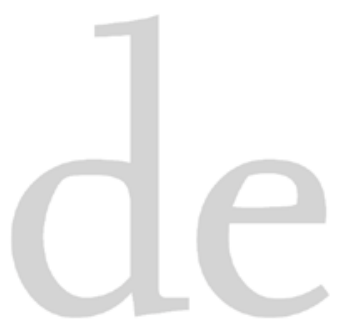

(Article begins on next page)

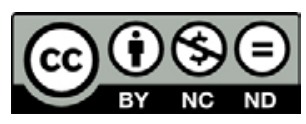

This work is licensed under a

Creative Commons Attribution-NonCommercial-NoDerivatives

4.0 International License. 


\section{Cleavage of Dinitrogen from Forming Gas by a Titanium Molecular System under Ambient Conditions}

Mariano González-Moreiras, Miguel Mena, Adrián Pérez-Redondo and Carlos Yélamos*

Departamento de Química Orgánica y Química Inorgánica, Universidad de Alcalá. 28805 Alcalá de Henares-Madrid (Spain). E-mail: carlos.yelamos@uah.es

Dedicated to Prof. Dr. Gerhard Erker on the occasion of his 70th birthday.

\section{Table of Contents:}

Commercially available $\mathrm{H}_{2} / \mathrm{N}_{2}$ mixture reacts with a hexane solution of $\left[\mathrm{Ti}\left(\eta^{5}-\mathrm{C}_{5} \mathrm{Me}_{5}\right) \mathrm{Me}_{3}\right]$ at ambient conditions to give a paramagnetic methylidene-methylidyne-nitrido cube-type complex via dinitrogen cleavage.

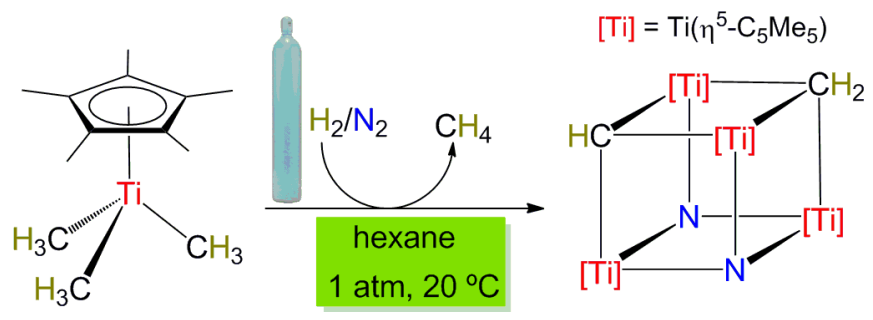




\begin{abstract}
:
Simple exposure of a hexane solution of $\left[\mathrm{TiCp}^{*} \mathrm{Me}_{3}\right]\left(\mathrm{Cp}^{*}=\eta^{5}-\mathrm{C}_{5} \mathrm{Me}_{5}\right)$ to an atmosphere of commercially available and inexpensive forming gas $\left(\mathrm{H}_{2} / \mathrm{N}_{2}\right.$ mixture, $13.5-16.5 \%$ of $\left.\mathrm{H}_{2}\right)$ at room temperature leads to the methylidene-methylidyne-nitrido cube-type complex $\left[\left(\mathrm{TiCp}^{*}\right)_{4}\left(\mu_{3}-\mathrm{CH}\right)\left(\mu_{3}-\mathrm{CH}_{2}\right)\left(\mu_{3}-\mathrm{N}\right)_{2}\right]$ via dinitrogen cleavage. This paramagnetic compound reacts with $\left[\mathrm{D}_{1}\right]$ chloroform to give the titanium(IV) methylidyne-nitrido species $\left[\left(\mathrm{TiCp}^{*}\right)_{4}\left(\mu_{3}-\mathrm{CH}\right)_{2}\left(\mu_{3}-\mathrm{N}\right)_{2}\right]$, whereas its one-electron oxidation with AgOTf or $\left[\mathrm{Fe}\left(\eta^{5}-\right.\right.$ $\left.\left.\mathrm{C}_{5} \mathrm{H}_{5}\right)_{2}\right](\mathrm{OTf})\left(\mathrm{OTf}=\mathrm{O}_{3} \mathrm{SCF}_{3}\right)$ yields the diamagnetic ionic derivative $\left[\left(\mathrm{TiCp}^{*}\right)_{4}\left(\mu_{3}-\right.\right.$ $\left.\mathrm{CH})\left(\mu_{3}-\mathrm{CH}_{2}\right)\left(\mu_{3}-\mathrm{N}\right)_{2}\right](\mathrm{OTf})$. The $\mu_{3}$-nitrido ligands of the methylidyne-nitrido cubane complex can be protonated with $[\mathrm{LutH}](\mathrm{OTf})(\mathrm{Lut}=2,6$-lutidine) or hydrogenated with $\mathrm{NH}_{3} \mathrm{BH}_{3}$ to afford $\mu_{3}-\mathrm{NH}$ imido moieties.
\end{abstract}

Keywords: cage compounds $\bullet$ methylidyne ligands $\bullet$ nitrides $\bullet$ nitrogen fixation $\bullet$ titanium 
There is a tremendous interest in the development of molecular systems capable of performing the catalytic conversion of $\mathrm{N}_{2}$ to $\mathrm{NH}_{3}$ under mild conditions. ${ }^{[1]}$ The industrial synthesis of ammonia in the Haber-Bosch process involves the treatment of a gas mixture of $\mathrm{N}_{2}$ and $\mathrm{H}_{2}$ under drastic pressure and temperature conditions using heterogeneous catalysts. ${ }^{[2]}$ The first step is believed to be the homolytic splitting of dinitrogen on the surface of the catalyst to give chemisorbed nitrogen atoms bridging several metal centers. ${ }^{[3]}$ Analogous reductive cleavage of $\mathrm{N}_{2}$ to form nitrido $\left(\mathrm{N}^{3-}\right)$ groups is now well-documented in molecular chemistry. ${ }^{[1]}$ The active species that break the $\mathrm{N} \equiv \mathrm{N}$ bond are low-valent transition metal complexes or derivatives generated by using strong reducing agents such as $\mathrm{KC}_{8}, \mathrm{Na}, \mathrm{K}$ or $\mathrm{KBHEt}_{3} .{ }^{[4]}$ An alternative route to avoid such reagents is the preparation of hydride complexes that activate $\mathrm{N}_{2}$ by elimination of $\mathrm{H}_{2}$ and may provide an entry to homogeneous systems using $\mathrm{H}_{2}$ as a reductant. ${ }^{[5]}$ Nowadays, only a few examples of molecular catalysis for $\mathrm{N}_{2}$ reduction to ammonia in solution are known. ${ }^{[6]}$ The methodology in those catalytic systems involves the addition of a high excess of external acids and reducing agents to well-defined molybdenum ${ }^{[6 a, b, d]}$, iron $^{[6 c, e]}$ or cobalt ${ }^{[6 f]}$ dinitrogen or nitrido complexes. Nevertheless, molecular hydrogen represents the desirable source of both protons and electrons mimicking the heterogeneous Haber-Bosch process.

Noteworthy, Hou and co-workers recently reported the synthesis of a hydrido-imido tetranuclear titanium complex $\left[\left(\mathrm{TiCp}^{\prime}\right)_{4}(\mu-\mathrm{H})_{4}\left(\mu_{3}-\mathrm{NH}\right)_{2}\right]\left(\mathrm{Cp}^{\prime}=\eta^{5}-\mathrm{C}_{5} \mathrm{Me}_{4} \mathrm{SiMe}_{3}\right)$ by reaction of $\left[\mathrm{TiCp}^{\prime}\left(\mathrm{CH}_{2} \mathrm{SiMe}_{3}\right)_{3}\right]$ with a $4: 1 \mathrm{H}_{2} / \mathrm{N}_{2}$ mixture at 5 atm and $60{ }^{\circ} \mathrm{C} .{ }^{[7]} \mathrm{A}$ combination of experimental and theoretical studies showed that $\mathrm{NH}$ imido groups are 
formed by dinitrogen cleavage and subsequent partial hydrogenation on a trinuclear titanium polyhydrido complex. The hydrido-imido tetranuclear species is also capable of cleaving $\mathrm{N}_{2}$ to give a imido-nitrido cube-type derivative $\left[\left(\mathrm{TiCp}^{\prime}\right)_{4}\left(\mu_{3}-\mathrm{N}\right)_{2}\left(\mu_{3}-\mathrm{NH}\right)_{2}\right]$, which is a useful nitrogen source for the preparation of nitriles. ${ }^{[8]}$ Here we report the preliminary results on the reaction of $\left[\mathrm{TiCp}^{*} \mathrm{Me}_{3}\right]\left(\mathrm{Cp}^{*}=\eta^{5}-\mathrm{C}_{5} \mathrm{Me}_{5}\right)$ with forming gas $\left(\mathrm{H}_{2} / \mathrm{N}_{2}\right.$ mixture, $13.5-16.5 \%$ of $\mathrm{H}_{2}$ ) to produce the paramagnetic methylidene-methylidyne-nitrido cluster $\left[\left(\mathrm{TiCp}^{*}\right)_{4}\left(\mu_{3}-\mathrm{CH}\right)\left(\mu_{3}-\mathrm{CH}_{2}\right)\left(\mu_{3}-\mathrm{N}\right)_{2}\right]$ (1) via dinitrogen cleavage under ambient conditions. Forming gas is a common, cheap and safe source of a reducing atmosphere of hydrogen in many laboratories. To gain information into the composition and properties of $\mathbf{1}$, we have studied its chemical oxidation to obtain diamagnetic derivatives and the subsequent functionalization by protonation and hydrogenation of the nitrido ligands.

The trimethyl derivative [ $\left.\mathrm{TiCp}^{*} \mathrm{Me}_{3}\right]$ in toluene is thermally stable under argon or dinitrogen atmosphere and decomposes at temperatures $\geq 95^{\circ} \mathrm{C}$ to the methylidyne cubane $\left[\left(\mathrm{TiCp}^{*}\right)_{4}\left(\mu_{3}-\mathrm{CH}\right)_{4}\right]$ and methane. ${ }^{[9]}$ However, exposure of a yellow hexane solution of [TiCp* $\mathrm{Me}_{3}$ ] to 1 atm of forming gas at room temperature resulted in the precipitation of $\mathbf{1}$ as dark brown crystals in $40 \%$ yield (Scheme 1). A higher yield of $\mathbf{1}(63 \%)$ was obtained by heating the reaction mixture at $65^{\circ} \mathrm{C}$. Whereas single crystals of $\mathbf{1}$ were also isolated when the reaction was performed in other non-coordinating solvents (toluene, benzene or fluorobenzene), the analogous treatment of pyridine or tetrahydrofuran solutions of [TiCp* $\left.\mathrm{Me}_{3}\right]$ with forming gas gave the starting mononuclear titanium complex unaltered. 


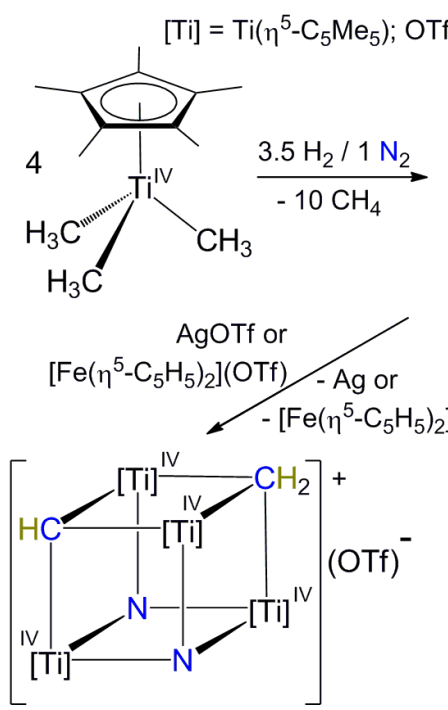

(3)

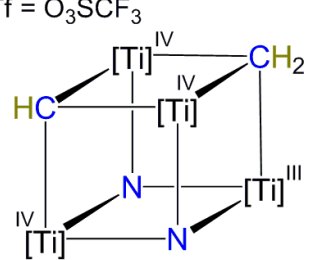

(1)

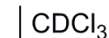

- $\mathrm{CHDCl} 2$ $-\left[\mathrm{Ti}^{5}\left(\eta^{5}-\mathrm{C}_{5} \mathrm{Me}_{5}\right) \mathrm{Cl}_{3}\right]$

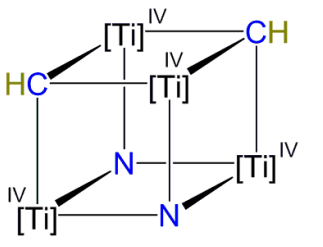

(2)

Scheme 1. Reaction of [ $\left.\mathrm{TiCp}^{*} \mathrm{Me}_{3}\right]$ with forming gas.

The crystal structure of $\mathbf{1}$ shows a Ti4 tetrahedron with each face capped by one $\mu_{3}-$ $\mathrm{EH}_{\mathrm{n}}(\mathrm{E}=\mathrm{C}$ or $\mathrm{N})$ ligand (Figure $\mathrm{S} 1$ in the Supporting Information). ${ }^{[10]}$ Thus, 1 contains an almost perfect $\left[\mathrm{Ti}_{4}\left(\mu_{3}-\mathrm{E}\right)_{4}\right]$ cube-type core, with averaged $\mathrm{E}-\mathrm{Ti}-\mathrm{E}$ and $\mathrm{Ti}-\mathrm{E}-\mathrm{Ti}$ angles of 89.3(5) and 90.7(9) ${ }^{\circ}$, respectively. The $\mathrm{Ti}-\mathrm{E}$ and $\mathrm{Ti}-\mathrm{Ti}$ separations (av. 2.005(18) and 2.854(16) $\AA$ respectively) range between those found in the cube-type methylidyne $\left[\left(\mathrm{TiCp}^{*}\right)_{4}\left(\mu_{3}-\mathrm{CH}\right)_{4}\right] \quad(\mathrm{av} . \mathrm{Ti}-\mathrm{C}=2.052(7) \text { and } \mathrm{Ti} \cdots \mathrm{Ti}=2.893(2) \AA)^{[9]}$ and nitrido $\left[\left(\mathrm{TiCp}^{*}\right)_{4}\left(\mu_{3}-\mathrm{N}\right)_{4}\right](\mathrm{av} . \mathrm{Ti}-\mathrm{N}=1.938(7) \text { and } \mathrm{Ti} \cdots \mathrm{Ti}=2.783(2) \AA)^{[11]}$ complexes. While the identity of the triply bridging ligands cannot be unambiguously established from the crystallographic data, they could be assigned as two $\mu_{3}-\mathrm{N}$, one $\mu_{3}-\mathrm{CH}$ and one $\mu_{3}-\mathrm{CH}_{2}$ groups according to spectroscopic data and reactivity studies. Thus, the ${ }^{1} \mathrm{H}$ NMR spectra in [D6]benzene or $\left[\mathrm{D}_{1}\right]$ chloroform show three far-downfield $(\delta=10.6-8.3 \mathrm{ppm})$ and broad resonances for the $\eta^{5}-\mathrm{C}_{5} \mathrm{Me}_{5}$ ligands in a $1: 1: 2$ ratio in accord with a $C_{\mathrm{s}}$ symmetry in solution. We have recently reported comparable resonance signals in the ${ }^{1} \mathrm{H}$ NMR spectra of several paramagnetic tetrametallic species with $\left[\mathrm{MTi}_{3}\left(\mu_{3}-\mathrm{NH}_{\mathrm{n}}\right)_{4}\right](\mathrm{M}=\mathrm{Y}, \mathrm{Ti}, \mathrm{Zr})$ cube- 
type cores where an unpaired electron is delocalized among the titanium atoms. ${ }^{[12]}$ The analogous paramagnetic nature of $\mathbf{1}$ was confirmed by an Evans method determination of its magnetic susceptibility ( $\mu_{\text {eff }}=1.92 \mu_{\mathrm{B}}, 293 \mathrm{~K}, \mathrm{CDCl}_{3}$ solution). The IR spectrum ( $\left.\mathrm{KBr}\right)$ of $\mathbf{1}$ is apparently uninformative but the lack of $\mathrm{N}-\mathrm{H}$ stretches ruled out the presence of $\mathrm{NH}$ functions in the compound. However, protonolysis of $\mathbf{1}$ with an excess of anhydrous hydrogen chloride $\left(1 \mathrm{M}\right.$ in $\left.\mathrm{Et}_{2} \mathrm{O}\right)$ in toluene at $60{ }^{\circ} \mathrm{C}$ afforded a white precipitate of $\mathrm{NH}_{4} \mathrm{Cl}$ (90\% for 2 equiv) and a red solution of $\left[\mathrm{TiCp}^{*} \mathrm{Cl}_{3}\right](86 \%$ for 4 equiv). In addition, the treatment of $\mathbf{1}$ in $\left[\mathrm{D}_{6}\right]$ benzene with deuterotrifluoromethanesulfonic acid (DOTf) gave a solution where $\mathrm{CH}_{2} \mathrm{D}_{2}\left(\delta=0.12 \mathrm{ppm}\right.$, quint, $\left.{ }^{2} J\left({ }^{1} \mathrm{H},{ }^{2} \mathrm{H}\right)=2.0 \mathrm{~Hz}\right)$ and $\mathrm{CHD}_{3}(\delta=0.11 \mathrm{ppm}$, sept, $\left.{ }^{2} J\left({ }^{1} \mathrm{H},{ }^{2} \mathrm{H}\right)=2.0 \mathrm{~Hz}\right)$ were detected by ${ }^{1} \mathrm{H}$ NMR spectroscopy.

Compound $\mathbf{1}$ is poorly soluble in hydrocarbon solvents, pyridine, or tetrahydrofuran but exhibits a good solubility in $\left[\mathrm{D}_{1}\right]$ chloroform, although it reacts slowly with this solvent at room temperature. The reaction of $\mathbf{1}$ with $\mathrm{CDCl}_{3}$ is faster at $85{ }^{\circ} \mathrm{C}$, and analysis by ${ }^{1} \mathrm{H}$ NMR spectroscopy of the resulting solution revealed resonance signals for $\mathrm{CHDCl}_{2}(\delta=$ $\left.5.32 \mathrm{ppm}, \mathrm{t},{ }^{2} J\left({ }^{1} \mathrm{H},{ }^{2} \mathrm{H}\right)=1.0 \mathrm{~Hz}\right),\left[\mathrm{TiCp}^{*} \mathrm{Cl}_{3}\right]$, and the diamagnetic methylidyne-nitrido species $\left[\left(\mathrm{TiCp}^{*}\right)_{4}\left(\mu_{3}-\mathrm{CH}\right)_{2}\left(\mu_{3}-\mathrm{N}\right)_{2}\right](2)$. Complex 2 was isolated in $60 \%$ yield as a dark brown solid through the reaction of 1 with $\mathrm{CDCl}_{3}$ ( $\geq 2$ equiv) in toluene at $85{ }^{\circ} \mathrm{C}$. The ${ }^{1} \mathrm{H}$ NMR spectrum of 2 in [D $D_{6}$ benzene shows two sharp singlets for the $\eta^{5}-\mathrm{C}_{5} \mathrm{Me}_{5}$ ligands in a 1:1 ratio in accordance with a $C_{2 \mathrm{v}}$ symmetry in solution. The methylidyne groups appear as a singlet at $\delta=15.24 \mathrm{ppm}$ in the ${ }^{1} \mathrm{H}$ NMR spectrum, and the ${ }^{13} \mathrm{C}\left\{{ }^{1} \mathrm{H}\right\}$ NMR signal of these ligands occurs at $\delta=393.7 \mathrm{ppm}$. Similar downfield resonances have been reported for other polynuclear titanium(IV) complexes with $\mu_{3}-\mathrm{CH}$ ligands. ${ }^{[9,13]}$

The paramagnetic complex $\mathbf{1}$ readily reacted with 1 equiv of silver(I) trifluoromethanesulfonate in toluene at room temperature to produce a brown solution and a 
dark precipitate containing the diamagnetic ionic derivative $\left[\left(\mathrm{TiCp}^{*}\right)_{4}\left(\mu_{3}-\mathrm{CH}\right)\left(\mu_{3}-\mathrm{CH}_{2}\right)\left(\mu_{3}-\right.\right.$ $\left.\mathrm{N})_{2}\right](\mathrm{OTf})(3)\left(\mathrm{OTf}=\mathrm{O}_{3} \mathrm{SCF}_{3}\right)$ and silver metal (Scheme 1). The solution was cooled to -30 ${ }^{\circ} \mathrm{C}$ to give a few deep red crystals of $3 \cdot \mathrm{C}_{7} \mathrm{H}_{8}$ suitable for an X-ray crystal structure determination. ${ }^{[10]}$ The crystal structure of 3 contains a cationic fragment with a $\left[\mathrm{Ti}_{4}\left(\mu_{3}-\right.\right.$ $\left.\mathrm{CH})\left(\mu_{3}-\mathrm{CH}_{2}\right)\left(\mu_{3}-\mathrm{N}\right)_{2}\right]$ cube-type core associated with the triflate anion through a $\mathrm{C}-\mathrm{H} \cdots \mathrm{O}$ hydrogen-bonding interaction ${ }^{[14]}$ between the methylidene ligand and one of the oxygen atoms $(\mathrm{C}(3) \cdots \mathrm{O}(12) \text { distance of } 3.391(7) \AA)^{[15]}$ (Figure 1). Furthermore, the methylidyne group is also involved in a $\mathrm{C}-\mathrm{H} \cdots \mathrm{O}$ hydrogen bond with an oxygen atom of another triflate anion $(\mathrm{C}(2) \cdots \mathrm{O}(11)$ a length of $3.485(7) \AA$ ) leading to zigzag chains (Figure S2). The existence of those interactions allows the unambiguous identification of all the triply bridging ligands in the cube-type $\left[\mathrm{Ti}_{4}\left(\mu_{3}-\mathrm{CH}\right)\left(\mu_{3}-\mathrm{CH}_{2}\right)\left(\mu_{3}-\mathrm{N}\right)_{2}\right]$ units of $\mathbf{3}$. Noteworthy, all Ti-N and Ti-C distances are within the narrow range of 2.038(4)-2.066(4) $\AA$ and the averaged $\mathrm{Ti}-\mathrm{E}(\mathrm{E}=\mathrm{C}$ or $\mathrm{N})$ and $\mathrm{Ti} \cdots \mathrm{Ti}$ separations of $2.050(10)$ and $2.844(13) \AA$ respectively, compare well with those found in $\mathbf{1 .}$

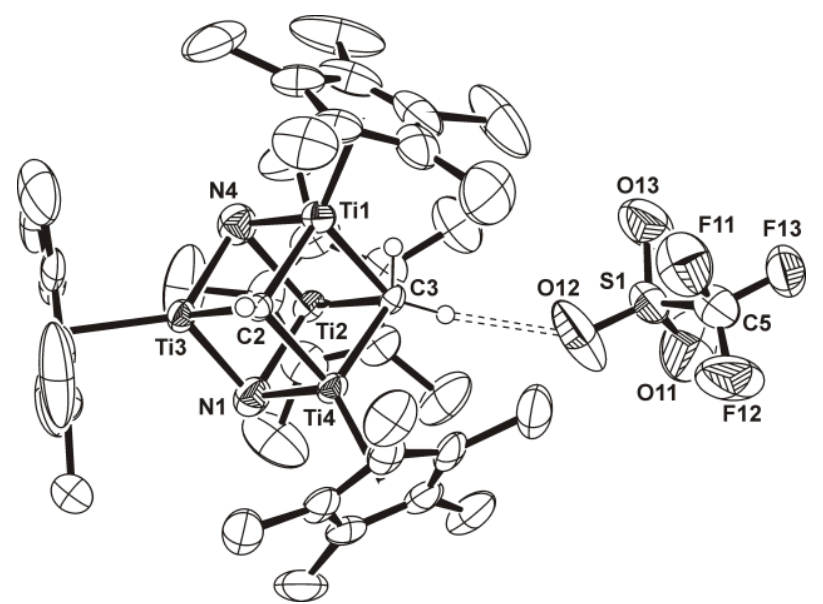

Figure 1. Perspective view of complex $3 \cdot \mathrm{C}_{7} \mathrm{H}_{8}$ (thermal ellipsoids at the $50 \%$ probability level). Hydrogen atoms of the $\eta^{5}-\mathrm{C}_{5} \mathrm{Me}_{5}$ ligands and the toluene solvent molecule are omitted for clarity. Selected averaged lengths $(\AA)$ and angles $\left(^{\circ}\right)$ : Ti-N 2.050(12), Ti-C(2) 


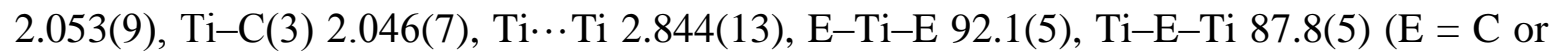
N).

Compound $\mathbf{3}$ was isolated in higher yield (51\%) as a dark brown precipitate by the treatment of 1 with 1 equiv of $\left[\mathrm{Fe}\left(\eta^{5}-\mathrm{C}_{5} \mathrm{H}_{5}\right)_{2}\right](\mathrm{OTf})$ in toluene at room temperature. The ionic complex $\mathbf{3}$ is virtually insoluble in common organic solvents and reacts immediately with $\left[\mathrm{D}_{1}\right]$ chloroform. The ${ }^{1} \mathrm{H}$ NMR spectrum of $\mathbf{3}$ in $\left[\mathrm{D}_{6}\right]$ benzene shows three sharp singlets for the $\eta^{5}-\mathrm{C}_{5} \mathrm{Me}_{5}$ groups in a 1:2:1 ratio in accordance with a $C_{\mathrm{s}}$ symmetry in solution. In addition, the spectrum reveals two singlets at $\delta=15.05$ and $3.34 \mathrm{ppm}$ attributable to one methylidyne and one methylidene ligands, respectively. Unfortunately, the low solubility of $\mathbf{3}$ in non-reactive solvents precluded its characterization by ${ }^{13} \mathrm{C}\left\{{ }^{1} \mathrm{H}\right\}$ NMR spectroscopy and other NMR experiments. To our knowledge, compound 3 represents the first structurally documented example of a methylidene bridging three group 4 metal centers, ${ }^{[16]}$ although several polymetallic rare-earth metal complexes with $\mu_{3}-\mathrm{CH}_{2}$ ligands have been reported. ${ }^{[17,18]}$

Protonation of $\mathbf{2}$ with 1 equiv of 2,6-lutidinium trifluoromethanesulfonate in toluene at room temperature led to the ionic derivative $\left[\left(\mathrm{TiCp}^{*}\right)_{4}\left(\mu_{3}-\mathrm{CH}\right)_{2}\left(\mu_{3}-\mathrm{N}\right)\left(\mu_{3}-\mathrm{NH}\right)\right](\mathrm{OTf})(4)$ (Scheme 2). Compound 4 was isolated in $56 \%$ yield as a green solid which is poorly soluble in hydrocarbon solvents at room temperature and reacts with $\left[\mathrm{D}_{1}\right]$ chloroform to give $\mathbf{2}$ and other unidentified products. However, complex $\mathbf{4}$ shows an enhanced solubility at higher temperatures, and through slow cooling of a heated benzene- $\mathrm{d}_{6}$ solution at $80{ }^{\circ} \mathrm{C}$, suitable single crystals of $4 \cdot \mathrm{C}_{6} \mathrm{D}_{6}$ for an $\mathrm{X}$-ray crystal structure determination were obtained. ${ }^{[10]}$ 


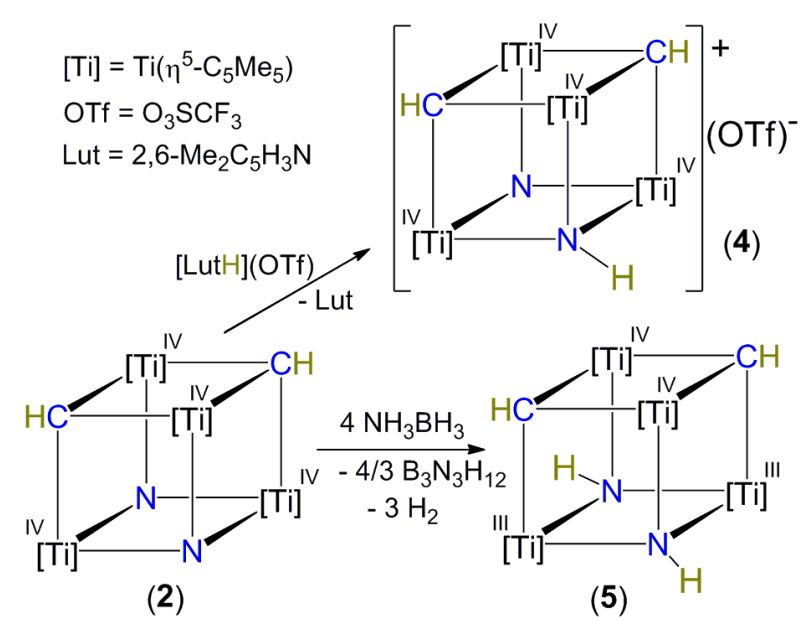

Scheme 2. Protonation and hydrogenation of 2.

The solid-state structure of complex 4 contains a cationic fragment with a $\left[\mathrm{Ti}_{4}\left(\mu_{3-}\right.\right.$ $\left.\mathrm{CH})_{2}\left(\mu_{3}-\mathrm{N}\right)\left(\mu_{3}-\mathrm{NH}\right)\right]$ cube-type core associated to the triflate anion through a $\mathrm{N}-\mathrm{H} \cdots \mathrm{O}$ hydrogen bonding interaction between the imido ligand and one of the oxygen atoms $(\mathrm{N}(1) \cdots \mathrm{O}(11)$ and $\mathrm{H}(1) \cdots \mathrm{O}(11)$ distances of 3.380(5) and 2.42(4) A respectively, and $\mathrm{N}(1)$ $\mathrm{H}(1) \cdots \mathrm{O}(11)$ angle of $175(4)^{\circ}$ ) (Figure 2). The averaged Ti-N(1) bond lengths of 2.048(9) $\AA$ are similar to the remaining $\mathrm{Ti}-\mathrm{E}(\mathrm{E}=\mathrm{C}$ or $\mathrm{N})$ distances within the cube-type core of 2.043(15) $\AA$. The IR spectrum $(\mathrm{KBr})$ shows one broad band at $3210 \mathrm{~cm}^{-1}$ for the $v_{\mathrm{NH}}$ vibration and several strong absorptions in the range $1280-1030 \mathrm{~cm}^{-1}$ for the triflate group. The ${ }^{1} \mathrm{H}$ NMR spectrum of 4 in $\left[\mathrm{D}_{6}\right]$ benzene at room temperature reveals three singlets in a 2:1:1 ratio for the $\eta^{5}-\mathrm{C}_{5} \mathrm{Me}_{5}$ ligands in accord with a $C_{\mathrm{s}}$ symmetric structure in solution. In addition, the spectrum shows a broad resonance signal at $\delta=14.72 \mathrm{ppm}$ for the $\mathrm{NH}$ group and a singlet at $\delta=15.59 \mathrm{ppm}$ for two methylidyne ligands. The low solubility of $\mathbf{4}$ in nonreactive solvents precluded its characterization by ${ }^{13} \mathrm{C}\left\{{ }^{1} \mathrm{H}\right\}$ NMR spectroscopy. 


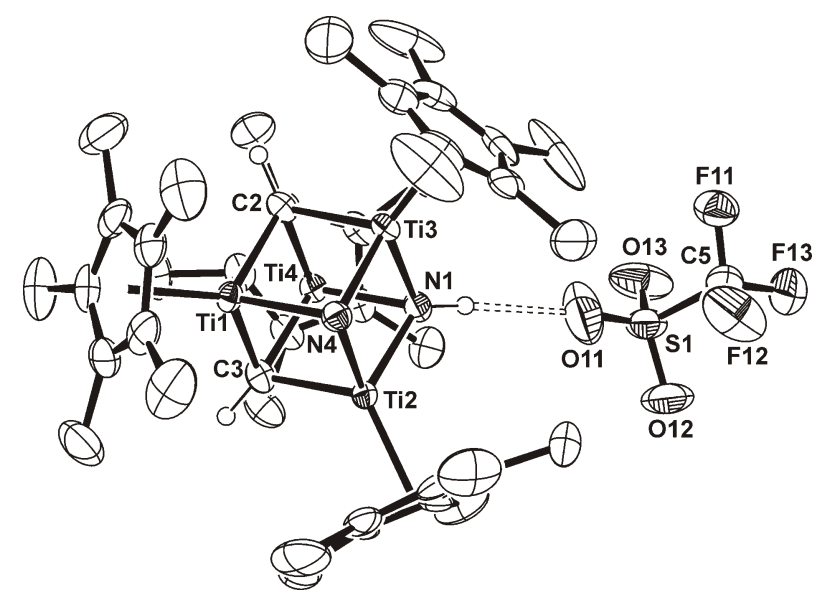

Figure 2. Perspective view of complex $4 \cdot \mathrm{C}_{6} \mathrm{D}_{6}$ (thermal ellipsoids at the $50 \%$ probability level). Hydrogen atoms of the $\eta^{5}-\mathrm{C}_{5} \mathrm{Me}_{5}$ ligands and the benzene solvent molecule are omitted for clarity. Selected averaged lengths $(\AA)$ and angles $\left({ }^{\circ}\right)$ : Ti-N(1) 2.048(9), Ti-E

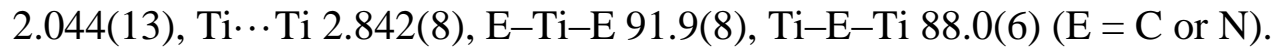

The treatment of 2 with 4 equiv of ammonia borane in toluene at $85{ }^{\circ} \mathrm{C}$ led to the imido-methylidyne cluster $\left[\left(\mathrm{TiCp}^{*}\right)_{4}\left(\mu_{3}-\mathrm{CH}\right)_{2}\left(\mu_{3}-\mathrm{NH}\right)_{2}\right](\mathbf{5})$ as a dark brown precipitate in $50 \%$ yield (Scheme 2). We have recently reported the partial hydrogenation of the nitrido complex $\left[\left(\mathrm{TiCp}^{*}\right)_{4}\left(\mu_{3}-\mathrm{N}\right)_{4}\right]$ with $\mathrm{NH}_{3} \mathrm{BH}_{3}$ (2 equiv) to give the paramagnetic imido-nitrido derivative $\left[\left(\mathrm{TiCp}^{*}\right)_{4}\left(\mu_{3}-\mathrm{N}\right)_{3}\left(\mu_{3}-\mathrm{NH}\right)\right]{ }^{[12 \mathrm{~b}]}$ In a fashion similar to that transformation, the reaction of 2 with $\mathrm{NH}_{3} \mathrm{BH}_{3}$ in $\left[\mathrm{D}_{8}\right]$ tetrahydrofuran at $85{ }^{\circ} \mathrm{C}$ was monitored by ${ }^{11} \mathrm{~B}$ NMR spectroscopy and the spectra showed one triplet resonance $\left[\delta=-10.5 \mathrm{ppm} ;{ }^{1} J(\mathrm{~B}, \mathrm{H})=101.4\right.$ $\mathrm{Hz}]$ assigned to cyclotriborazane $\left(\mathrm{CTB}\right.$; $\left.\left[\mathrm{NH}_{2} \mathrm{BH}_{2}\right]_{3}\right)$ and minor resonance signals for borazine and polyborazylene ${ }^{[19]}$ However, the diamagnetic nature of $\mathbf{5}$ is consistent with the hydrogenation of the two $\mu_{3}$-nitrido ligands of 2 with concomitant two-electron reduction of the $\mathrm{Ti}_{4}$ core similar to that observed in the electronic structure of $\left[(\mathrm{RCC}) \mathrm{Zn}\left\{\left(\mu_{3}-\mathrm{NH}\right)_{3} \mathrm{Ti}_{3} \mathrm{Cp}_{3}\left(\mu_{3}-\mathrm{NCCR}\right)\right\}\right]{ }^{[20]}$ The molecular structure of 5 shows a [Ti4 $\left(\mu_{3}-\right.$ E) 4] cube-type core (Figure S3) similar to those found for complexes 1, 3 and 4, with 
averaged $\mathrm{Ti}-\mathrm{E}(\mathrm{E}=\mathrm{C}$ or $\mathrm{N})$ and $\mathrm{Ti}-\mathrm{Ti}$ distances of 2.040(4) and 2.809(1) $\AA$, respectively. ${ }^{[10]}$ The ${ }^{1} \mathrm{H}$ NMR spectrum of 5 in $\left[\mathrm{D}_{1}\right]$ chloroform shows two sharp singlets for the $\eta^{5}-\mathrm{C}_{5} \mathrm{Me}_{5}$ groups in a $1: 1$ ratio, one singlet at $\delta=15.68 \mathrm{ppm}$ for two methylidyne ligands and a broad resonance signal at $\delta=12.72 \mathrm{ppm}$ for the $\mathrm{NH}$ groups in accordance with a $C_{2 v}$ symmetry in solution. The IR spectrum $(\mathrm{KBr})$ shows the $\mathrm{N}-\mathrm{H}$ stretching modes at 3309 and $3259 \mathrm{~cm}^{-1}$ as the two absorptions expected for $C_{2 \mathrm{v}}$ symmetry $\left(\mathrm{A}_{1}\right.$ and $\mathrm{B}_{2}$ vibrations).

In summary, we have shown that hydrocarbon solutions of $\left[\mathrm{TiCp}^{*} \mathrm{Me}_{3}\right]$ react with forming gas under ambient conditions to give the paramagnetic tetranuclear methylidenemethylidyne-nitrido complex $\left[\left(\mathrm{TiCp}^{*}\right)_{4}\left(\mu_{3}-\mathrm{CH}\right)\left(\mu_{3}-\mathrm{CH}_{2}\right)\left(\mu_{3}-\mathrm{N}\right)_{2}\right] \quad(\mathbf{1})$ via dinitrogen cleavage. One-electron oxidation of $\mathbf{1}$ yielded titanium(IV) diamagnetic derivatives which are more amenable to detailed structural characterization and reactivity studies. Thus, the $\mu_{3}$-nitrido ligands of $\left[\left(\mathrm{TiCp}^{*}\right)_{4}\left(\mu_{3}-\mathrm{CH}\right)_{2}\left(\mu_{3}-\mathrm{N}\right)_{2}\right](2)$, derived from dinitrogen splitting, can be subsequently functionalized by partial protonation or hydrogenation to yield $\mu_{3}-\mathrm{NH}$ imido moieties. The presence of $\mu_{3}$-methylidene and $\mu_{3}$-methylidyne groups in $\mathbf{1}$ is indicative of the incomplete hydrogenolysis of all the titanium-carbon(methyl) bonds in the mononuclear $\left[\mathrm{TiCp}^{*} \mathrm{Me}_{3}\right]$ precursor. ${ }^{[21]} \mathrm{We}$ are currently investigating the reactivity of other early transition metal complexes with $\mathrm{H}_{2} / \mathrm{N}_{2}$ mixtures with the aim to uncover more novel findings in the area of molecular nitrogen activation and functionalization. ${ }^{[22]}$

\section{Acknowledgements}

We thank the Spanish MINECO (CTQ2013-44625-R) and Universidad de Alcalá (CCG2015/EXP-026) for financial support of this research. M.G.-M. thanks the MECD for a doctoral fellowship. 


\section{References}

[1] For selected recent reviews, see: a) S. Hinrichsen, H. Broda, C. Gradert, L. Söncksen, F. Tuczek, Annu. Rep. Progr. Chem., Sect. A: Inorg. Chem. 2012, 108, 17-47; b) Y. Tanabe, Y. Nishibayashi, Coord. Chem. Rev. 2013, 257, 2551-2564; c) C. J. M. van der Ham, M. T. M. Koper, D. G. H. Hetterscheid, Chem. Soc. Rev. 2014, 43, 51835191; d) C. Sivasankar, S. Baskaran, M. Tamizmani, K. Ramakrishna, J. Organomet. Chem. 2014, 752, 44-58; e) Y. Nishibayashi, Inorg. Chem. 2015, 54, 9234-9247; f ) H. Tanaka, Y. Nishibayashi, K. Yoshizawa, Acc. Chem. Res. 2016, 49, 987-995.

[2] For original references and a recent book on the industrial synthesis of ammonia, see: a) F. Haber, Z. Elektrochem. 1910, 16, 244-246; b) F. Haber, R. Le Rossignol, US971501, 1910; c) F. Haber, R. Le Rossignol, Z. Elektrochem. 1913, 19, 53-72; d) H. Liu, Ammonia Synthesis Catalysts, Chemical Industry Press \& World Scientific, Singapore, 2013.

[3] a) R. Schlögl, in Handbook of Heterogeneous Catalysis, 2nd ed. (Eds. G. Ertl, G. Knözinger, F. Schüth, J. Weitkamp), Wiley-VCH, Weinheim, 2008, vol. 5, pp. 25012575; b) G. Ertl, Angew. Chem. Int. Ed. 2008, 47, 3524-3535; Angew. Chem. 2008, $120,3578-3590$.

[4] For leading references, see: a) C. E. Laplaza, C. C. Cummins, Science 1995, 268, 861-863; b) A. Zanotti-Gerosa, E. Solari, L. Giannini, C. Floriani, A. Chiesi-Villa, C. Rizzoli, J. Am. Chem. Soc. 1998, 120, 437-438; c) G. K. B. Clentsmith, V. M. E. Bates, P. B. Hitchcock, F. G. N. Cloke, J. Am. Chem. Soc. 1999, 121, 10444-10445; d) F. Akagi, T. Matsuo, H. Kawaguchi, Angew. Chem. Int. Ed. 2007, 46, 8778-8781; Angew. Chem. 2007, 119, 8934-8937; e) M. Hirotsu, P. P. Fontaine, A. Epshteyn, P. Y. Zavalij, L. R. Sita, J. Am. Chem. Soc. 2007, 129, 9284-9285; f) G. B. Nikiforov, I. 
Vidyaratne, S. Gambarotta, I. Korobkov, Angew. Chem. Int. Ed. 2009, 48, 74157419; Angew. Chem. 2009, 121, 7551-7555; g) M. M. Rodríguez, E. Bill, W. W. Brennessel, P. L. Holland, Science 2011, 334, 780-783; h) A. J. Keane, B. L. Yonke, M. Hirotsu, P. Y. Zavalij, L. R. Sita, J. Am. Chem. Soc. 2014, 136, 9906-9909; i) Y. Ishida, H. Kawaguchi, J. Am. Chem. Soc. 2014, 136, 16990-16993; j) K. Grubel, W. W. Brennessel, B. Q. Mercado, P. L. Holland, J. Am. Chem. Soc. 2014, 136, 1680716816; k) T. Miyazaki, H. Tanaka, Y. Tanabe, M. Yuki, K. Nakajima, K. Yoshizawa, Y. Nishibayashi, Angew. Chem. Int. Ed. 2014, 53, 11488-11492; Angew. Chem. 2014, 126, 11672-11676; 1) Y. Lee, F. T. Sloane, G. Blondin, K. A. Abboud, R. García-Serres, L. J. Murray, Angew. Chem. Int. Ed. 2015, 54, 1499-1503; Angew. Chem. 2015, 127, 1519-1523.

[5] a) M. D. Fryzuk, Acc. Chem. Res. 2009, 42, 127-133; b) J. Ballmann, R. F. Munhá, M. D. Fryzuk, Chem. Commun. 2010, 46, 1013-1025; c) H.-P. Jia, E. A. Quadrelli, Chem. Soc. Rev. 2014, 43, 547-564.

[6] a) D. V. Yandulov, R. R. Schrock, Science 2003, 301, 76-78; b) K. Arashiba, Y. Miyake, Y. Nishibayashi, Nat. Chem. 2011, 3, 120-125; c) J. S. Anderson, J. Rittle, J. C. Peters, Nature 2013, 501, 84-87; d) K. Arashiba, E. Kinoshita, S. Kuriyama, A. Eizawa, K. Nakajima, H. Tanaka, K. Yoshizawa, Y. Nishibayashi, J. Am. Chem. Soc. 2015, 137, 5666-5669; e) T. J. Del Castillo, N. B. Thompson, J. C. Peters, J. Am. Chem. Soc. 2016, 138, 5341-5350; f) S. Kuriyama, K. Arashiba, H. Tanaka, Y. Matsuo, K. Nakajima, K. Yoshizawa, Y. Nishibayashi, Angew. Chem. Int. Ed. 2016, 55, 14291-14295; Angew. Chem. 2016, 128, 14503-14507.

[7] T. Shima, S. Hu, G. Luo, X. Kang, Y. Luo, Z. Hou, Science 2013, 340, 1549-1552.

[8] M. M. Guru, T. Shima, Z. Hou, Angew. Chem. Int. Ed. 2016, 55, 12316-12320; Angew. Chem. 2016, 128, 12504-12508. 
[9] R. Andrés, P. Gómez-Sal, E. de Jesús, A. Martín, M. Mena, C. Yélamos, Angew. Chem. Int. Ed. Engl. 1997, 36, 115-117; Angew. Chem. 1997, 109, 72-74.

[10] CCDC $1517464(\mathbf{1}), 1517465\left(\mathbf{3} \cdot \mathrm{C}_{7} \mathrm{H}_{8}\right), 1517466\left(\mathbf{4} \cdot \mathrm{C}_{6} \mathrm{D}_{6}\right)$, and $1517467(\mathbf{5})$ contain the supplementary crystallographic data for this paper. These data can be obtained free of charge from The Cambridge Crystallographic Data Centre via www.ccdc.cam.ac.uk/data_request/cif. For details of the X-ray crystallographic studies, see the Supporting Information.

[11] P. Gómez-Sal, A. Martín, M. Mena, C. Yélamos, J. Chem. Soc., Chem. Commun. 1995, 2185-2186.

[12] a) J. Caballo, J. J. Carbó, M. Mena, A. Pérez-Redondo, J.-M. Poblet, C. Yélamos, Inorg. Chem. 2013, 52, 6103-6109; b) J. Caballo, M. González-Moreiras, M. Greño, M. Mena, A. Pérez-Redondo, C. Yélamos, Inorg. Chem. 2014, 53, 8851-8853; c) J. Caballo, M. Greño, M. Mena, A. Pérez-Redondo, C. Yélamos. Dalton Trans. 2015, $44,18145-18157$.

[13] a) R. Andrés, M. Galakhov, A. Martín, M. Mena, C. Santamaría, J. Chem. Soc., Chem. Commun. 1995, 551-552; b) A. Abarca, M. Galakhov, P. Gómez-Sal, A. Martín, M. Mena, J.-M. Poblet, C. Santamaría, J. P. Sarasa, Angew. Chem. Int. Ed. Engl. 2000, 39, 534-537; Angew. Chem. 2000, 112, 544-547.

[14] T. Steiner, Crystallogr. Rev. 1996, 6, 1-51.

[15] W. P. Schaefer, R. W. Quan, J. E. Bercaw, Acta Crystallogr., Sect. C 1992, 48, 16101612.

[16] For homometallic titanium complexes containing $\mu-\mathrm{CH}_{2}$ ligands, see: a) L. Scoles, $\mathrm{R}$. Minhas, R. Duchateau, J. Jubb, S. Gambarotta, Organometallics 1994, 13, 49784983; b) O. Buitrago, C. Ramírez de Arellano, G. Jiménez, T. Cuenca, 
Organometallics 2004, 23, 5873-5876; c) J. J. Carbó, O. González-del-Moral, A. Martín, M. Mena, J.-M. Poblet, C. Santamaría, Eur. J. Inorg. Chem. 2009, 643-653.

[17] For homometallic rare-earth metal complexes containing $\mu_{3}-\mathrm{CH}_{2}$ ligands, see: a) $\mathrm{H}$. M. Dietrich, K. W. Törnroos, R. Anwander, J. Am. Chem. Soc. 2006, 128, 92989299; b) M. Zimmermann, D. Rauschmaier, K. Eichele, K. W. Törnroos, R. Anwander, Chem. Commun. 2010, 46, 5346-5348; c) W.-X. Zhang, Z. Wang, M. Nishiura, Z. Xi, Z. Hou, J. Am. Chem. Soc. 2011, 133, 5712-5715; d) J. Hong, L. Zhang, X. Yu, M. Li, Z. Zhang, P. Zheng, M. Nishiura, Z. Hou, X. Zhou, Chem. Eur. J. 2011, 17, 2130-2137; e) T. Li, M. Nishiura, J. Cheng, Y. Li, Z. Hou, Chem. Eur. J. 2012, 18, 15079-15085; f) T. Li, M. Nishiura, J. Cheng, W. Zhang, Y. Li, Z. Hou, Organometallics 2013, 32, 4142-4148.

[18] Heterometallic cuboid complexes containing bridging methylidene and methylidyne ligands have been previously reported, see: L. C. H. Gerber, E. Le Roux, K. W. Törnroos, R. Anwander, Chem. Eur. J. 2008, 14, 9555-9564.

[19] We have assigned the triplet resonance to cyclotriborazane (CTB), but other cyclic oligomers of different ring sizes (e.g. cyclodiborazane, CDB) cannot be ruled out, see: a) J. S. Wang, R. A. Geanangel, Inorg. Chim. Acta 1988, 148, 185-190; b) W. J. Shaw, J. C. Linehan, N. K. Szymczak, D. J. Heldebrant, C. Yonker, D. M. Camaioni, R. T. Baker, T. Autrey, Angew. Chem. Int. Ed. 2008, 47, 7493-7496; Angew. Chem. 2008, 120, 7603-7606.

[20] J. J. Carbó, A. Martín, M. Mena, A. Pérez-Redondo, J.-M. Poblet, C. Yélamos, Angew. Chem. Int. Ed. 2007, 46, 3095-3098; Angew. Chem. 2007, 119, 3155-3158.

[21] The hydrogenolysis of [ $\left.\mathrm{TiCp}^{*} \mathrm{Me}_{3}\right]$ with $\mathrm{H}_{2}$ (1 atm) under $\mathrm{N}_{2}$-free conditions at room temperature afforded a paramagnetic titanium compound with a tetranuclear structure according to an X-ray crystal structure determination. However, the identity of the 
bridging ligands cannot be unambiguously established from the crystallographic data, and we are currently investigating the reactivity of this compound to gain information into its composition.

[22] During the revision of this article, Hou and co-workers have reported the dinitrogen activation by dihydrogen and a PNP-ligated titanium complex at room temperature, see: B. Wang, G. Luo, M. Nishiura, S. Hu, T. Shima, Y. Luo, Z. Hou, J. Am. Chem. Soc. 2017, 139, DOI: 10.1021/jacs.6b13323. 